Research Article

\title{
Quantitative and Qualitative Composition of Soil Organic Matter in Samples of Ice Complex from Central Yakutia, Eastern Siberia
}

\author{
Andrey Shepelev ${ }^{D},{ }^{1}$ Alexander Fedorov, ${ }^{1,2}$ and Alexandra Cherepanova ${ }^{1}$ \\ ${ }^{1}$ Melnikov Permafrost Institute, Siberian Branch of the Russian Academy of Sciences, Yakutsk 677010, Russia \\ ${ }^{2}$ Biogeoscience Educational and Scientific Trainings, North-Eastern Federal University, Yakutsk 677000, Russia \\ Correspondence should be addressed to Andrey Shepelev; saqaliba868@gmail.com
}

Received 25 October 2017; Revised 12 January 2018; Accepted 13 May 2018; Published 30 May 2018

Academic Editor: Rafael Clemente

Copyright (c) 2018 Andrey Shepelev et al. This is an open access article distributed under the Creative Commons Attribution License, which permits unrestricted use, distribution, and reproduction in any medium, provided the original work is properly cited.

Investigation of organic carbon and nitrogen stock was conducted at depths greater than one meter in the ice complex in central part of Yakutia (Russia). Around 53\% of the total organic carbon stock in the upper part of the ice complex is held in the active layer. The protective layer holds $31 \%$ and the permafrost layer holds $16 \%$. The distribution of nitrogen over the elementary layers of the ice complex mirrors the percentages for organic carbon stocks given above. The total stock of biogenic elements in the ice complex investigated $(0-250 \mathrm{~cm})$ consists of $38.7 \pm 0.2 \mathrm{~kg} / \mathrm{m}^{2}$ of organic carbon and $2.13 \pm 0.01 \mathrm{~kg} / \mathrm{m}^{2}$ of nitrogen. The prevalent amount is carbon detritus, $40 \%$ of the total carbon content in the active layer. The share of labile carbon accounts $18 \%$, that is 2 times less than carbon detritus. In the next two layers, the content of the components decreases and varies from $2 \%$ to $12 \%$. The low labile organic matter content in the protective and permafrost layers indicates the development of the ice complex proceeded under conditions with poorly formed organic material.

\section{Introduction}

According to one investigation based on geocryological interpretation of the Baikal climate chronicle, permafrost arose about 3.1 million years ago [1], and according to another, 2 million years ago, together with the cooling of the climate on the Earth [2]. In the era of transformation of the climate system, the transitional stage of the cycle change are cooling and warming. Permafrost is a dynamic natural phenomenon of the northern latitudes and mountainous regions of the planet, and it is characterized by high ice content of permafrost rocks of the Middle Pleistocene age and the instability of thermal equilibrium. In modern conditions, when the natural environment in the circumpolar region of permafrost is changing, there is an issue of what critical causes influence on degradation processes of permafrost. There is a huge amount of biogenic elements in various forms (carbon and nitrogen) in permafrost and various degrees of decomposition. Due to the climate warming and permafrost destruction, they will lead to the release into the atmosphere of greenhouse gases, such as $\mathrm{CO}_{2}, \mathrm{CH}_{4}$, and $\mathrm{N}_{2} \mathrm{O}$ [3-5]. It should be expected that natural processes proceed slowly in geological time; their speed is incommensurable with the speed of processes caused by anthropogenic (technogenic) factors. The observed changes in anthropogenic features are increasingly developing and have a predominant effect on the evolution of permafrost sequences at the regional and planetary scale. It should be noted that $25 \%$ of global land area and $65 \%$ of the territory of Russia is occupied by permafrost [2].

A review of available scientific literature on organic matter stocks held in soils and permafrost underlying the circumpolar region shown that the majority of this research has been carried in Arctic and sub-Arctic regions of Russia and northern America, and main research objects were tundra and forest tundra [6-15]. Less data are available for boreal regions [11, 16-20].

According to estimates $[19,21]$ conducted on the soil area of $17.8 \times 10^{6} \mathrm{~km}^{2}, 1307 \mathrm{Gt}$ of soil carbon (C) with fluctuations from 1140 to $1476 \mathrm{Gt} \mathrm{C}$ are held in permafrost. It is 
approximately $50 \%$ of the global pool of ground C. The authors estimated $472 \mathrm{Gt}$ of carbon storage for the upper meter of soil and for the 1-2 m depth interval around $355 \mathrm{Gt}$. According to Russian researchers [22, 23], about $67 \%$ of terrestrial ecosystem C is held in the soil, about $1395 \mathrm{Gt}$, of which $192 \mathrm{Gt}$ or $14 \%$ are in tundra and forest tundra ecosystems, and in boreal forests, there is $13 \%$, where it was deposited mainly in the layers of permafrost. Based on the estimates, the boreal region, as the entire circumpolar region, acts as sinks of organic substances in the soil, despite their low primary productivity [24]. One of the leading roles belongs to the labile organic matter (LOM) including plant residues with varying degrees of decomposition and humification, as well as humus substances that are weakly bound to the mineral part of the soil. The LOM of frozen rocks strongly depends on the type of vegetation [25] and the degree of development of thermokarst, as well as significant amounts of LOM conserved in the deep layers of permafrost, which will become available for microbial decomposition when ground temperatures rise and continuous thawing occurs $[26,27]$. A lot of fractions of LOM can be distinguished from soil, but for quality assessment of the organic matter of the soil, it is enough to use mortmass, detritus, and labile carbon. Based on the number and relationship between these fractions, it is possible to say about the level of the biological state of the soil and the biogeochemical processes occurring in the pedosphere. Moreover, the study of these fractions at an approximate value would allow us to correct the estimated criteria in organic carbon losses due to permafrost thawing. At the same time, the current state of organic matter in soil depends on the number of factors, where climate conditions, landscape structure, the type of vegetation cover, physico chemical, and biological properties of the soil are the most important. In natural ecosystems, the equilibrium is maintained by the state of supply and loss of organic matter; therefore, the organic carbon content and reserves can remain unchanged for an indefinite time in the absence of cryogenic processes, as well as local or planetary climate changes.

The purpose of our work is to evaluate the biogenic elements and labile organic matter in the active, protective, and permafrost layers of the ice complex that is in the stage of destabilization of the established soil system at its present stage of development. The indicators discussed can be used as indicators of possible changes in the reserves of organic matter in the boreal region as a result of the temperature rise in permafrost, which in turn will lead to increased cryogenic processes, as well as mineralization and physical losses of organic matter.

\section{Materials and Methods}

2.1. Study Area. Studies were carried out at the Chyuya monitoring range of Melnikov Permafrost Institute of Siberian Branch of the Russian Academy of Sciences, on the right bank of Lena river. It is located in the coordinates $61^{\circ} 43^{\prime} \mathrm{N}$, $130^{\circ} 25^{\prime} \mathrm{E}$ (Figure 1). In geological and geomorphological terms, the research area belongs to inter-rivers Lena and Amga and part of the Central Yakutia lowland lying in the province of the Central Siberian Upland [28], and from the landscape point of view, it is located on Lena-Amginsky alas province of the physical-geographical country of Central Siberia [29]. The region is characterized by a wide development of thermokarst forms of relief [28]. The research area is a typical landscape of Central Yakutia, containing huge ice wedges (ice complex) and extensive alas. The surface tilts slightly to the northwest and at the level of 200-220 $\mathrm{m}$ a.s.l. Ice wedges in undisturbed areas occur at a depth of 2-2.5 m. The width of their upper part varies from 1 to 1.5 to $2.5-3 \mathrm{~m}$. The volume content of ice in these sediments reaches $50 \%$. The depth of seasonal thawing varies from 1.2 to $2.5 \mathrm{~m}$, depending on the landscape conditions [30]. Formation of ice complex (IC) deposits in Central Yakutia occurred under severe climatic conditions of the late Pleistocene (from 13,700 \pm 530 to $22,300 \pm 1200$ years ago) at a soil temperature of no higher than $10^{\circ} \mathrm{C}[31]$.

The climate of the region is highly continental resulting in sharp variations in temperature between the coldest month (January) and the warmest month (July). Winter temperatures range from $-35^{\circ} \mathrm{C}$ to $-45^{\circ} \mathrm{C}$ and below. The sum of positive temperatures higher than $10^{\circ} \mathrm{C}$ is around $1400^{\circ} \mathrm{C}-1600^{\circ} \mathrm{C}$, and the average annual precipitation is around $200-300 \mathrm{~mm}$.

In soil-geographic zoning, the territory is part of the temperate-cold belt of the East Siberian permafrost-taiga region and the Central Yakut province of the mid-taiga subzone of the cryogenic-taiga (Cryosols) and pale (Haplic Cambisols) soils. In this paper, the soils of the study territory are classified within the international system World Reference Base for Soil Resources (WRB) [32]. Figure 2 shows the demonstration materials of the Chyuya monitoring range and the description of soil section in Table 1.

In the botanical section, the research area refers to the middle-taiga larch forests (Larix gmelinii and L. cajanderi). In facial terms, the site is confined to limnas (Limnas stelleri) cranberries in combination with larch and Alder forests, areas of alas grass (Calamagrostis langsdorffi) and sedge (Carex juncella) meadows.

Map fragment of the investigated territory is composed in "ArcGIS 10 version 10.1," and also the materials of the Yandex Maps server were used.

2.2. Terms Used in Geocryology and Various Scientific Articles. Permafrost is a phenomenon of long-term freezing of the upper part of the lithosphere, as well as the thickness and range of permafrost [33].

Alas is a flat thermokarst hollow up to several tens of square kilometers, which arises in the region of ice-covered permafrost as a result of ground ice melting and uneven subsidence of soils and the surface [33].

The ice complex or yedoma is loess-like syngenetic frozen soils of the Pleistocene age with high thickness, forming the northern coastal lowlands, the plains of Central Yakutia, and the northeast. The ice complex is characterized by high ice content of sediments up to $70-90 \%$ and large syngenetic ice lodes, with heights up to $60-80 \mathrm{~m} \mathrm{[33].}$ 


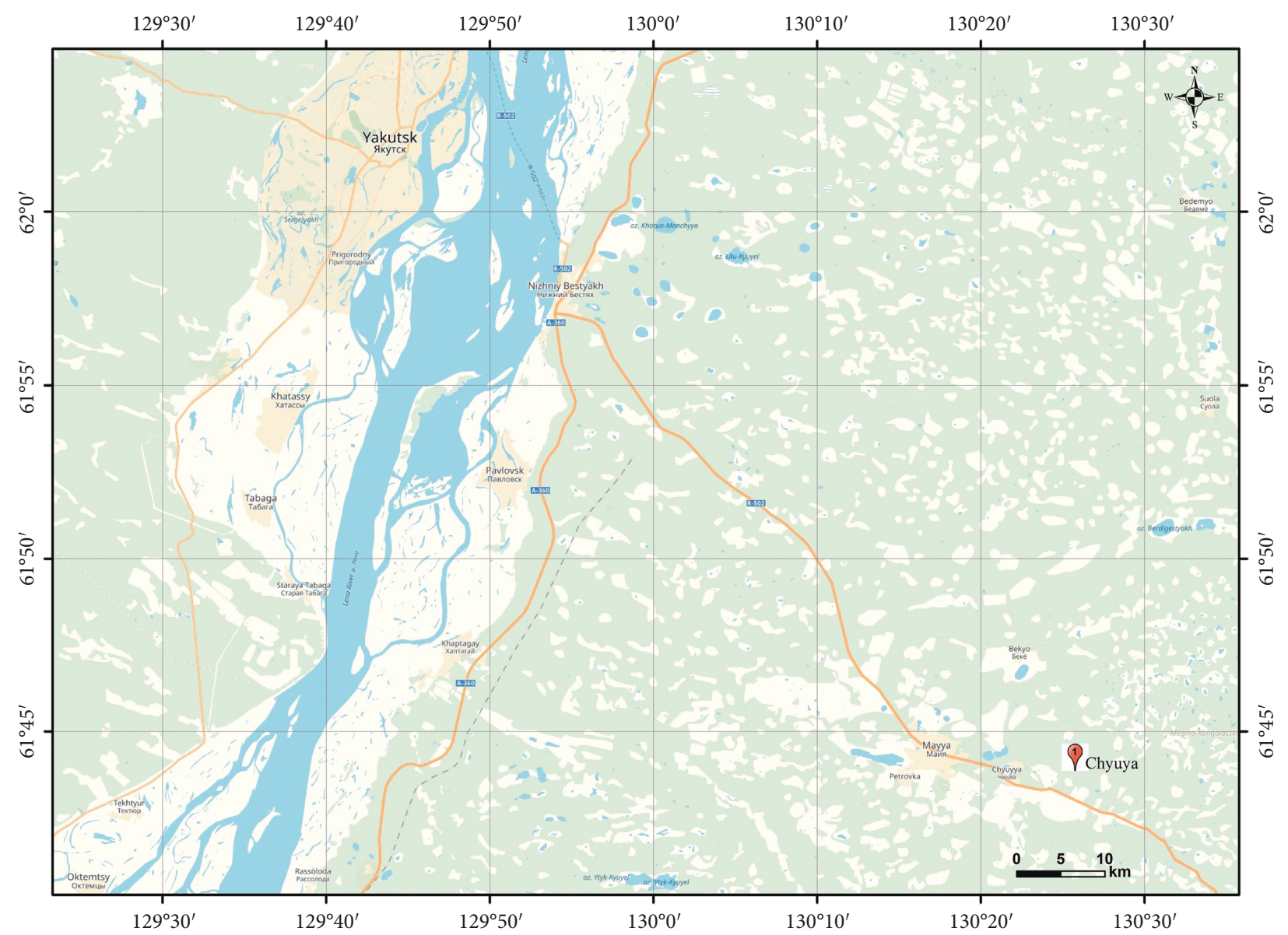

Figure 1: Location of the study area "Chyuya," shown on a scheme of the region.

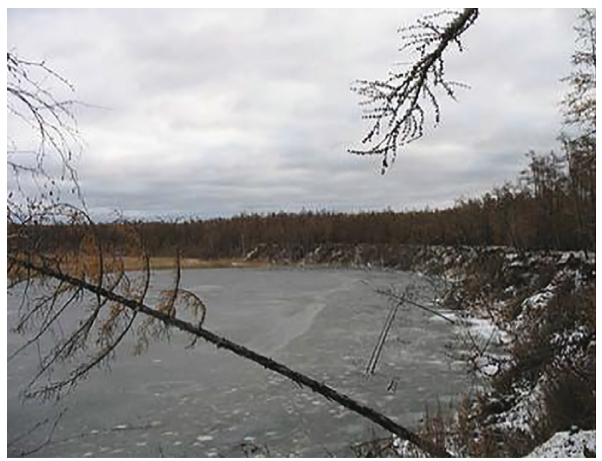

(a)



(b)

FIgURe 2: The general view of the thermokarst lake (a), formed as a result of the melting of the ice complex on the monitoring range "Chyuya"; a soil section of Cryosols Haplic Cambisols Dystric of the investigated ice complex (b).

Ice wedge is the ice filling frost fissure, as well as other cracks in the field of permafrost. During thawing out of ice wedges, ditches up to $5-10 \mathrm{~m}$ at the depth and up to 10-15 $\mathrm{m}$ width are formed, which are filled with soil mass [33].

Active layer is the uppermost layer of soil alternately freezing and thawing in the presence of permafrost at its base [33].

Protective or transitional layer is a surface layer, which thaws during favorable climatic conditions, joins the active layer, but during unfavorable conditions it does thaw and is the upper layer of permafrost [34].

Permanently frozen layer is the state of soil, existing without interruption for many years, centuries, and millennia at a negative temperature [33].

Cryogenic processes are set of processes of physical, chemical, and mineralogical changes and transformation of soils and rocks of the weathering crust, as well as hydrosphere at a negative temperature [33]. 
TABle 1: Morphological description of Cryosols Haplic Cambisols Dystric soil section on the ice complex.

\begin{tabular}{|c|c|c|}
\hline Horizon & $\begin{array}{l}\text { Depth } \\
(\mathrm{cm})\end{array}$ & Diagnostics \\
\hline Oi & $0-4$ & $\begin{array}{l}\text { Forest litter from pine needles, lichens, } \\
\text { cones, dead parts of plants }\end{array}$ \\
\hline A1 & $4-10$ & $\begin{array}{c}\text { Coarse humus horizon, dark brown, strongly } \\
\text { permeated with living roots of woody and } \\
\text { herbaceous plants, loose, moist, jagged, } \\
\text { wavy border }\end{array}$ \\
\hline A 2 & $10-30$ & $\begin{array}{l}\text { Pale, dense, horizontal swims of humus, the } \\
\text { presence of thin roots, slightly moist, the } \\
\text { transition is sharp, the boundary is uneven }\end{array}$ \\
\hline $\mathrm{Ba}$ & $30-40$ & $\begin{array}{l}\text { Gray, dense, slightly permeated with small } \\
\text { living roots, slightly moist, gradual } \\
\text { transition, smooth boundary }\end{array}$ \\
\hline $\mathrm{B}_{\mathrm{Ca}}$ & $40-6$ & $\begin{array}{l}\text { Gray, single presence of thin roots, gradual } \\
\text { transition, weak effervescence from } 10 \% \mathrm{HCl}\end{array}$ \\
\hline $\mathrm{Cr}$ & $60-120$ & $\begin{array}{l}\text { Gray, rare inclusions of iron oxide, } \\
\text { lies on the surface of permafrost }\end{array}$ \\
\hline
\end{tabular}

Thermokarst is the process of thawing of frozen grounds and ground ice, accompanied by the formation of subsidence forms of relief [33].

Lode ice is a kind of ground ice. It forms when water fills cracks in rocks and unconsolidated permafrost rocks. They have a diverse material composition of impurities, the presence of vertical and inclined banding. It is formed due to repeated repetition of ice formation in the same lode [33].

Labile carbon is a slightly decomposable pool of soil organic matter formed by plant and animal residues that enter the soil, and detritus is an intermediate decomposition product not associated with the mineral part of the soil. According to the chemical composition, labile carbon is represented by lignin, carbohydrates, amino acids, peptides, and other nonspecific compounds, as well as carbon of humic acids and fulvic acids [35].

Detrital carbon is a light fraction of soil organic matter, separated by a heavy liquid ( $\mathrm{NaI}, \mathrm{KI}$, and $\left.\mathrm{KI}+\mathrm{CdI}_{2}\right)$. Part of the organic matter of the soil, relatively easily decomposed by soil microorganisms, is presented in the soil mainly in the form of mobile compounds of carbon and plant residues of various degrees of decomposition [35].

2.3. Analyses of Organic Matter in Permafrost. For conducting of geochemical analyses, soil samples from the ice complex were collected every $10 \mathrm{~cm}$ to the upper limit of permafrost $(250 \mathrm{~cm})$ with three replications. After the sampling was completed, the biogenic elements proceeded to take the soil density in a natural condition using steel cylinders of $100 \mathrm{~cm}^{3}$. The formula for calculating soil density is given below.

Preparation of soil samples took place under laboratory conditions at the room temperature. The primary soil material was laid out on paper and dried to an air-dry state. Then air-dried soil samples were passed through a sieve with a cell diameter of $0.5 \mathrm{~mm}$, and the large roots were removed from the samples.
The content of organic carbon $(\mathrm{OC})$ and nitrogen $(\mathrm{N})$ in the active layer of permafrost Cryosols Haplic Cambisols Dystric soils, as well as in permafrost IC, was determined on a CN "Thermo scientific Flash 2000" element analyzer at a specimen combustion temperature of $900^{\circ} \mathrm{C}$. Before loading the soil samples into the autosampler of the instrument, they were dried in a thermal cabinet at a temperature of $40^{\circ} \mathrm{C}$ to exclude water and distortion of the analysis results.

Labile carbon (CL) was determined by direct extraction of $0.1 \mathrm{M} \mathrm{NaOH}$ and daily exposure. A saturated solution of $\mathrm{Na}_{2} \mathrm{SO}_{4}$ was used to coagulate the silty particles and accelerate the filtration [36]. Carbon detritus (CD) was monitored by separating this fraction with a heavy $\mathrm{NaI}$ (sodium iodide) liquid with a density of $1.8 \mathrm{gm} / \mathrm{cm}^{3}$. The essence of the method is that when a sample is mixed with a heavy liquid, particles whose density is less than or equal to the density of the liquid float to the surface, while denser ones remain in the sediment [37]. The analyses were then carried out on a Cary-50 Agilent Technologies spectrophotometer at an optical density of $590 \mathrm{~nm}$. The solution volume in the cuvette was $4.5 \mathrm{ml}$. The $\mathrm{CD}$ content was calculated from the difference between the total carbon content in the original soil and its content in the same soil after separation of the CD.

The soil density of natural condition was determined by the drilling method (cylinder), every $10 \mathrm{~cm}$, knowing the mass of the pump with the soil and the weight of the empty pump, and the difference was found in the mass of the soil at a given humidity. Determining the moisture percentage, the mass of absolutely dry soil was calculated. By dividing the mass of absolutely dry soil by its volume (cylinder volume), the soil density of undisturbed addition was obtained. The OC $\left(\mathrm{kg} / \mathrm{m}^{2}\right)$ and $\mathrm{N}\left(\mathrm{kg} / \mathrm{m}^{2}\right)$ reserves were calculated for each $10 \mathrm{~cm}$ of the selected layer using the C\% and $\mathrm{N} \%$ content and the bulk density $\left(\mathrm{g} / \mathrm{cm}^{3}\right)$. The depth increments were interpolated using the samples. The reserves were calculated for several elementary layers: The upper $0-120 \mathrm{~cm}$ (active layer of soil), $120-200 \mathrm{~cm}$ of protective layer, and $200-$ $250 \mathrm{~cm}$ of permafrost layer. The calculation of the total carbon and nitrogen reserves of the organic matter of the soil was carried out:

$$
S=H \rho X,
$$

where $S$ is the reserves of $\mathrm{OC}$ and $\mathrm{N}$ in the soil of the ice complex, $\mathrm{kg} / \mathrm{m}^{2} ; H$ is the thickness of layer, $\mathrm{cm} ; \rho$ is the density of the soil, $\mathrm{g} / \mathrm{cm}^{3} ; X$ is the average content of OC, and $\mathrm{N}$ in the soil of the ice complex, \%.

The statistical processing of the data was carried out in the StatSoft STATISTICA for Windows 6.1 program. The data are presented as arithmetic means with standard deviations.

\section{Results and Discussion}

In our investigations, layers deeper than 1 meter, which are in the permafrost state for a long time, were of great interest, with the accumulation of soil organic matter (SOM) occurring not only in the active layer, in the present stage of soil formation, but also in the permafrost sequences of the 
TABLE 2: Characteristics of soil organic matter: the distribution of stocks and the average organic carbon (OC) and nitrogen (N) content in the elementary layers of the ice complex.

\begin{tabular}{lccc}
\hline Index & \multicolumn{3}{c}{$\begin{array}{c}\text { Layer, cm } \\
120-200\end{array}$} \\
\hline Content OC, \% & $3.0 \pm 0.04$ & $1.2 \pm 0.01$ & $1.0 \pm 0.03$ \\
(active) & $\begin{array}{c}\text { (protective) } \\
\text { (permafrost) }\end{array}$ \\
Content N, \% & $0.14 \pm 0.01$ & $0.06 \pm 0.01$ & $0.05 \pm 0.01$ \\
$\mathrm{C} / \mathrm{N}$ ratio & $21 \pm 0.3$ & $20 \pm 0.1$ & $20 \pm 0.1$ \\
Storage OC, $\mathrm{kg} / \mathrm{m}^{2}$ & $20.5 \pm 0.1$ & $11.9 \pm 0.1$ & $6.3 \pm 0.2$ \\
Storage N, $\mathrm{kg} / \mathrm{m}^{2}$ & $1.24 \pm 0.01$ & $0.54 \pm 0.01$ & $0.35 \pm 0.01$ \\
\hline
\end{tabular}

Means \pm standard deviations $(n=3)$.

Pleistocene epoch, which may include significant archaic quantities of OC, N, and other components of SOM. We will say that the presence of SOM in permafrost layers is the result of past accumulation and the conserved part of the previous Pleistocene epoch. Consequently, the SOM was formed from two geological epochs: Pleistocene and Holocene, that is, by adding them. In other words, the older organic matter is supplemented with the newly formed modern soil organic matter. This process is manifested in the reserves and distribution of accumulated OC in the permafrost. Therefore, when cyclic shifts are recorded in the construction and change of the temperature regime flow in the permafrost zone, the thawing of permafrost from above is the result of an increase in their temperature, which will lead to the destruction of the conserved organic matter and subsequently to the enhancement of mineralization losses in the form of $\mathrm{CO}_{2}$ and $\mathrm{CH}_{4}$.

Calculations showed (Table 2) that the absolute reserves of OC and $\mathrm{N}$ in the differentiated layers of IC differ significantly from one another. Thus, the active layer has the maximum reserves, in which $53 \% \mathrm{OC}$ and $58 \% \mathrm{~N}$ are concentrated from the total reserves in the soil. The protective layer contains $31 \%$ OC and $25 \% \mathrm{~N}$ of the total reserves. The minimum reserves are confined to the permafrost layer $16 \%$ for each indicator. As can be seen, the active layer has an active IC layer due to the presence in it of half-decomposed and decomposed woody and plant residues, including abundant presence of basic and subtle roots. The presence of organic components in the lower layers is explained by the fact that under conditions of low temperatures, they are contained in stable compounds and their accumulation in the protective and permafrost layers is not directly related to the SOM. The current view on this account suggests that gravitational and cryogenic migrations of mobile humic substances penetrate deeper along the soil stratum to permafrost. Consequently, humic substances with a slow decomposition rate under low temperature conditions gradually accumulate down the profile [13].

The composition of SOM contains only $5 \%-10 \%$ nitrogen [38]. This amount is sufficient for the optimal mineralization process between organic components in the conditions of the subboreal belt and the maintenance of a high content of organic carbon in the soil. That cannot be said about the ecosystems of the moderately cold climate, which includes boreal forests and permafrost soils.
The processes of destruction and mineralization of organic matter in them occur mainly in the upper annually thawing layer, and the microbiological activity of the soil has low values; therefore, a considerable amount of nitrogen is found in the hardly decomposable organic matter. As a consequence, low $\mathrm{N}$ reserves are observed in all studied soil layers: the total $\mathrm{N}$ reserves in the soil layer IC $0-250 \mathrm{~cm}$ are only $2.13 \mathrm{~kg} / \mathrm{m}^{2}$. The $\mathrm{C} / \mathrm{N}$ ratio serving as the index of SOM enrichment with nitrogen, in the active layer is 21 ; with depth, it decreases slightly. This indicates that the soil formed by IC is nitrogen and indirectly indicates a low mineralization of SOM. First, the high content of carbon and low nitrogen in the soil promotes a weak decomposition by microorganisms of incoming and conserved organic material. This is due to a decrease in the process of ammonification in nitrogen-poor environments. Secondly, in the moderately cold climate, the mineralization processes of the SOM proceed in a slow rhythm. During a short and warm summer period, only a small part of the organic matter decomposes to carbon dioxide, water, and mineral salts, and a layer of weakly decomposed plant and animal remains in the form of an organic horizon is formed on the surface of the soil. There is no authentic difference in $\mathrm{C} / \mathrm{N}$, and therefore we do not focus attention on the unreliable index.

The labile organic matter (LOM) has a contrasting character in the permafrost IC (Table 3). This is due to the mechanisms of its formation and the time of turnover in extreme climatic conditions. LOM in the active layer interacts more with environmental factors, and its decomposition requires less cost compared to the LOM fractions of the lower layers, so the CL and CD of the active layer can be attributed to the fractions of the unprotected organic matter in the soil, which are subjected to greater loading by microorganisms. CL and CD protective and permafrost layers are characterized by inaccessibility to microorganisms due to their presence in frozen rocks at a negative temperature.

Besides the climatic environment where LOM soils are formed, one of the decisive roles is the vegetation type, its productivity and cryogenic processes occurring in permafrost soils [25].

In the soil organic matter, the fraction of detrital carbon predominates, the carbon content of detritus decreases by a factor of 58, and the labile carbon by only 5-13 times. Probably, the low labile organic matter content deep in the profile of the ice complex is explained by low initial stocks in the Pleistocene epoch. Either anatomical particle exhaustion or its loss of labile organic matter is a result of long-term burial in extreme climatic conditions.

The maximum content of fractions of labile organic matter in the upper active layer of soil is due to the fact that they are renewed during the growing season by fresh organic material, potentially available for decomposition and subject to interannual fluctuations of the environment. The composition of soil organic matter is twice as much carbon detritus as labile carbon. Such a significant excess of one fraction over another is that labile carbon is formed due to the very detritus of various degrees of decomposition, as well as plant and animal residues that have entered the soil. Two 
TABLE 3: The average labile carbon (CL) and carbon detritus (CD) content of soil organic matter for various fractions of the ice complex.

\begin{tabular}{|c|c|c|c|c|}
\hline \multirow{2}{*}{ Layer $(\mathrm{cm})$} & $\mathrm{CL}$ & $\mathrm{CD}$ & & $\mathrm{CD}$ \\
\hline & \multicolumn{2}{|c|}{$\mathrm{g} / \mathrm{kg}$ soil } & \multicolumn{2}{|c|}{$\%$ from $\mathrm{OC}$} \\
\hline Active $(0-120)$ & $52 \pm 0.5$ & $117 \pm 2.7$ & 18 & 40 \\
\hline Protective (120-2 & $4 \pm 0.01$ & $2 \pm 0.01$ & 3 & 2 \\
\hline Permafrost (200-250) & $11 \pm 0.4$ & $2 \pm 0.01$ & 12 & 2 \\
\hline
\end{tabular}

Means \pm standard deviations $(n=3)$.

of these fractions directly participate in the formation of a labile part of soil organic matter, where there are conditions for the arrival of plant and animal residues and their destruction and mineralization.

A separate consideration is required for the soil formation factor of the podzolic type in the given territory. In previous studies, we have shown [39] that biogenic elements are redistributed in the soil profile intermittently. Their content is high in the horizon of $\mathrm{Al}$ and from its lower boundary rapidly decreases downward and then sharply increases in horizon $\mathrm{C}$. In the horizon $\mathrm{B}$, the content of organic carbon and nitrogen remains low, probably due to the insufficient chemical weathering of this horizon under given conditions. It can be said that the entire profile of the section is washed with solutions of humic substances, since traces of humic infiltration are observed, yellowing horizons for the washing of organic substances. Taking this into account, it can be concluded that the direction of the transformation of plant residues in Cryosols Haplic Cambisols Dystric is the processes of hydrolysis and oxidation of plant substances of predominantly carbohydrate character with a weakly expressed nitrogen exchange and a suppressed mineralization process.

In the active layer, LOM is regulated by humidity and temperature, since during warm summer season, this layer warms up and thaws more than the lower layers, thereby controlling the degree of decomposition of plant residues in the soil. It was shown [35] that decomposition of stable compounds of organic matter at a low temperature is retained more strongly than labile ones. It is also necessary to note the effect of the presence of nitrogen in the soil, which affects the mineralization of the organic matter of the soil. With a high nitrogen content in plant tissues or in soil, decomposition accelerates and nitrogen-induced rapid mineralization of labile components leads to a decrease in carbon stocks [40]. Low nitrogen in the soil inhibits mineralization processes and the formation of labile forms of organic matter.

Thus, due to the lack of influence of negative cryogenic processes on SOM and its structural components, LOM will remain stable for tens and hundreds of years. Now, the amount of preserved LOM is low, which is evident in our studies. If average permafrost temperatures increase or permafrost thawing occurs, the climax of the original state LOM will change, as CL and CD are considered as quickly mineralized materials of SOM; as a result, $\mathrm{CO}_{2}$ emission will increase in the atmosphere. With the increase in $\mathrm{CO}_{2}$ emission, the productivity of plant communities will increase, which will affect the accumulation of large stocks of SOM; this is one of the positive aspects of change. On the other hand, firstly, changes in the natural or man-made nature will violate the vulnerable state of the LOM, especially they can be seen in the ecosystems of the boreal regions, which will entail a restructuring of the established order. Secondly, large stocks of organic matter will degrade physically, not having time to decompose to the final product of mineralization.

\section{Conclusion}

Studies have shown that the total organic carbon and nitrogen stocks at a depth of $250 \mathrm{~cm}$ in the ice complex of Central Yakutia were $38.7 \mathrm{~kg} / \mathrm{m}^{2}$ and $2.13 \mathrm{~kg} / \mathrm{m}^{2}$, respectively. Much of the OC reserves is $53 \%$ and $\mathrm{N}-58 \%$ is concentrated in the active layer of the soil. In the protective layer, $31 \%$ of organic carbon and $25 \%$ of nitrogen are conserved. Orders below $\mathrm{OC}$ and $\mathrm{N}$ are in the permafrost layer of $16 \%$ for each index. Due to the complexity of soil organic matter and various agents of its transformation, the division into labile fractions gives an idea of the composition of soil organic matter and its resistance to environmental conditions. The process of formation of labile organic matter in the soil of Central Yakutia is determined by several factors: the flow of forest plant biomass onto the soil surface and the rate of its decomposition; the initial reservoirs of organic material, enclosed in the rocks of the ice complex; the strength of the occurrence of permafrost and their thawing during the summer period; and the landscape situation of the territory. In fact, these factors are controlled by the thermal regime associated with a certain type of soil formation-podzolic. Along with the lowered temperature and the short vegetative period, the special biogeochemical direction of process of transformation of the vegetable remains and their impact on mineral thickness of the soil is allocated. Perhaps, this is the exclusive specificity of the transformation of biogenic elements and the labile organic matter of the soil in the ice complex of Central Yakutia.

In natural ecosystems, when there is an equilibrium between intake and losses of organic matter, the stocks of biogenic elements can remain unchanged for long periods of time, if there are no negative external factors affecting their changes. Otherwise, the known cryogenic processes as a result of the derivative climate will provoke inevitable losses of soil organic matter.

\section{Conflicts of Interest}

The authors declare that they have no conflicts of interest.

\section{Acknowledgments}

The authors would like to express their gratitude to the scientific staff of the Siberian Federal Scientific Centre of Agro-BioTechnologies of the Russian Academy of Sciences, Novosibirsk, for their assistance in analyzing the labile organic matter from the permafrost. The authors are sincerely grateful to their colleagues in the International Scientific and Educational Center for Biogeochemistry and Climatology of the North-Eastern Federal University, Yakutsk, for conducting analyses of organic carbon and nitrogen. 


\section{References}

[1] S. M. Fotiev, "Siberian geocryological chronicles," Kriosfera Zemli, vol. 3, pp. 3-16, 2009, in Russian.

[2] N. A. Shpolyanskaya, Permafrost and Global Climate Changes, Institute of Computer Sciences Publishing, Izhevsk, Russia, 2010.

[3] O. A. Anisimov, "Potential feedback of thawing permafrost to the global climate system through methane emission," Environmental Research Letters, vol. 2, no. 4, pp. 7-15, 2007.

[4] C. Tarnocai, J. G. Canadell, E. A. G. Schuur, P. Kuhry, G. Mazhitova, and S. Zimov, "Soil organic carbon pools in the northern circumpolar permafrost region," Global Biogeochemical Cycles, vol. 23, no. 2, pp. 2023-2033, 2009.

[5] E. A. G. Schuur, A. D. McGuire, C. Schadel et al., "Climate change and the permafrost carbon feedback," Nature, vol. 520, no. 7546, pp. 171-179, 2015.

[6] Y. Matsuura, A. P. Abaimov, O. A. Zyryanova, and A. P. Isaev, "Carbon and nitrogen storage of mountain forest tundra soils in central and eastern Siberia," in Proceedings of the Fifth Symposium on the Joint Siberian Permafrost Studies between Japan and Russia in 1996, Tsukuba, Japan, 1996.

[7] O. V. Chestnykh, D. G. Zamolodchikov, and D. V. Karelin, "Resources of organic carbon in the soils of tundra and foresttundra ecosystems in Russia," Russian Journal of Ecology, vol. 30, pp. 392-398, 1999.

[8] P. Kuhry, G. G. Mazhitova, P.-A. Forest, S. V. Deneva, T. Virtanen, and S. Kultti, "Upscaling soil organic carbon estimates for the Usa Basin (Northeast European Russia) using GIS-based land cover and soil classification schemes," Geografisk Tidsskrift-Danish Journal of Geography, vol. 102, no. 1, pp. 11-25, 2002.

[9] J. G. Bockheim, "Importance of cryoturbation in redistributing organic carbon in permafrost-affected soils," Soil Science Society of America Journal, vol. 71, no. 4, pp. 13351342, 2007.

[10] G. Grosse, J. Harden, M. Turetsky et al., "Vulnerability of high-latitude soil organic carbon in North America to disturbance," Journal of Geophysical Research Biogeosciences, vol. 116, p. G00K06, 2011.

[11] G. Hugelius, T. Virtanen, D. Kaverin et al., "High-resolution mapping of ecosystem carbon storage and potential effects of permafrost thaw in periglacial terrain, European Russian Arctic," Journal of Geophysical Research Biogeosciences, vol. 116, p. G03024, 2011.

[12] M. Kanevskiy, Y. Shur, D. Fortier, M. T. Jorgenson, and E. Stephani, "Cryostratigraphy of late Pleistocene syngenetic permafrost (yedoma) in northern Alaska, Itkillik river exposure," Quaternary Research, vol. 75, no. 3, pp. 584-596, 2011.

[13] N. S. Mergelov and V. O. Targulian, "Accumulation of organic matter in the mineral layers of permafrost-affected soils of coastal lowlands in East Siberia," Eurasian Soil Science, vol. 44, no. 3, pp. 249-260, 2011.

[14] C. E. Hicks Pries, E. A. G. Schuur, and K. G. Crummer, "Holocene carbon stocks and carbon accumulation rates altered in soils undergoing permafrost thaw," Ecosystems, vol. 15, no. 1, pp. 162-173, 2012.

[15] J. Strauss, L. Schirrmeister, S. Wetterich, A. Borchers, and S. P. Davydov, "Grain-size properties and organic-carbon stock of yedoma ice complex permafrost from the Kolyma lowland, northeastern Siberia," Global Biogeochemical Cycles, vol. 26, no. 3, p. GB3003, 2012.

[16] C. L. Ping, G. J. Michaleson, E. S. Kane et al., "Carbon stores and biogeochemical properties of soils under black spruce forest Alaska," Soil Science Society of America Journal, vol. 74, no. 3, pp. 969-978, 2010.

[17] P. Kuhry, G. Grosse, J. W. Harden et al., "Characterisation of the permafrost carbon pool," Permafrost and Periglac Process, vol. 24, no. 2, pp. 146-155, 2013.

[18] D. G. Schepaschenko, A. Z. Shvidenko, L. V. Mukhortova, and E. F. Vedrova, "The pool of organic carbon in the soils of Russia," Eurasian Soil Science, vol. 46, no. 2, pp. 107-116, 2013.

[19] M. B. Siewert, J. Hanisch, N. Weiss, P. Kuhry, T. C. Maximov, and G. Hugelius, "Comparing carbon storage of Siberian tundra and taiga permafrost ecosystems at very high spatial resolution," Journal of Geophysical Research Biogeosciences, vol. 120, no. 10, pp. 1973-1994, 2015.

[20] A. Bartsch, B. Widhalm, P. Kuhry, G. Hugelius, J. Palmtag, and M. B. Siewert, "Can C-band synthetic aperture radar be used to estimate soil organic carbon storage in tundra," Biogeosciences, vol. 13, no. 19, pp. 5453-5470, 2016.

[21] G. Hugelius, J. Strauss, S. Zubrzycki et al., "Estimated stocks of circumpolar permafrost carbon with quantified uncertainty ranges and identified data gaps," Biogeosciences, vol. 11, no. 23 , pp. 6573-6593.

[22] D. V. Karelin, D. G. Zamolodchikov, and T. G. Gilmanov, "Reserves and production of carbon in the phytomass of tundra and forest-tundra ecosystems in Russia," Russian Forest Sciences, vol. 5, pp. 29-36, 1995.

[23] O. V. Chestnykh, D. G. Zamolodchikov, and A. I. Utkin, "General reserves of bioremediation of carbon and nitrogen in the soil of the forest fund of Russia," Russian Forest Sciences, vol. 4, pp. 30-42, 2004.

[24] A. Rodionow, H. Flessa, O. Kazansky, and G. Guggenberger, "Organic matter composition and potential trace gas production of permafrost soils in the forest tundra in northern Siberia," Geoderma, vol. 135, pp. 49-62, 2006.

[25] W. Shang, X. Wu, L. Zhao et al., "Seasonal variations in labile soil organic matter fractions in permafrost soils with different vegetation types in the central Qinghai-Tibet Plateau," $\mathrm{Ca}$ tena, vol. 137, pp. 670-678, 2016.

[26] J. W. Harden, C. D. Koven, C.-L. Ping et al., "Field information links permafrost carbon to physical vulnerabilities of thawing," Geophysical Research Letters, vol. 39, no. 15, p. L15704, 2012.

[27] C. W. Mueller, J. Rethemeyer, J. Kao-Kniffin, S. Loppmann, K. M. Hinkel, and J. Bockheim, "Large amounts of labile organic carbon in permafrost soils of northern Alaska," Global Change Biology, vol. 21, no. 7, pp. 2804-2817, 2015.

[28] P. A. Solov'ev, Cryolithozone of Northern Part of Lena-Amga Interfluve, USSR Academy of Sciences Publishing, Moscow, Russia, 1959, in Russian.

[29] P. I. Mel'nikov, The Permafrost-Landscape Map of the Yakut ASSR, Scale 1:2500000, Main Department of Geodesy and Cartography Publishing, Moscow, Russia, 1991, in Russian.

[30] A. N. Fedorov and P. Y. Konstantinov, "Observations of surface dynamics with thermokarst initiation, Yukechi site, Central Yakutia," in Permafrost, M. Phillips, S. Springman, and L. U. Arenson, Eds., Swets \& Zeitlinger, Lisse, Netherlands, 2003.

[31] E. M. Katasonov, M. S. Ivanov, G. G. Pudov, and C. Zigert, Structure and Absolute Geochronology of Alas Sediments in Central Yakutia, Nauka Publishing, Novosibirsk, Russia, 1979, in Russian.

[32] IUSS Working Group WRB, World Reference Base for Soil Resources 2014, Update 2015, Food and Agriculture Organization, Rome, Italy, 2015. 
[33] V. V. Baulin and V. E. Murzaeva, Eds., Geocryological Glossary, GEOS Publishing, Moscow, Russia, 2003, in Russian.

[34] Y. L. Shur, Thermokarst, Nedra Publishing, Moscow, Russia, 1977, in Russian.

[35] V. M. Semenov and B. M. Kogut, Soil Organic Matter, GEOS Publishing, Moscow, Russia, 2015, in Russian.

[36] V. V. Ponomareva and T. A. Plotnikova, Humus and Soil Formation (Methods and Results of the Study), Nauka Publishing, Leningrad, Russia, 1980, in Russian.

[37] N. F. Ganzhara, Soil Science, Agrokonsalt Publishing, Moscow, Russia, 2001, in Russian.

[38] D. S. Orlov, O. N. Biryukova, and N. I. Sukhanova, Soil Organic Matter of Russia, Nauka Publishing, Moscow, Russia, 1996, in Russian.

[39] A. G. Shepelev, E. V. Starostin, A. N. Fedorov, and T. Maximov, "Preliminary analysis of stocks of organic carbon and nitrogen in the upper part of the ice complex in Central Yakutia," Nauka i Obrazovanie, vol. 82, no. 2, pp. 35-42, 2016.

[40] K. Fog, "The effect of added nitrogen on the rate of decomposition of organic matter," Biological Reviews, vol. 63, no. 3, pp. 433-462, 1988. 

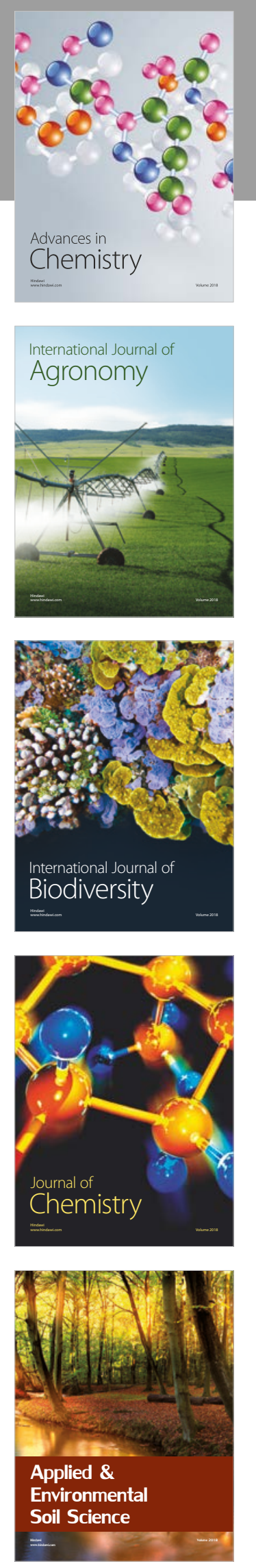

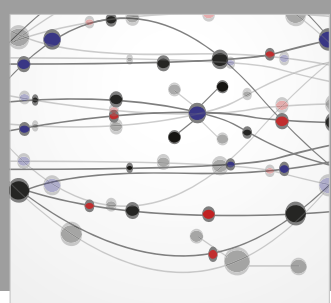

The Scientific World Journal

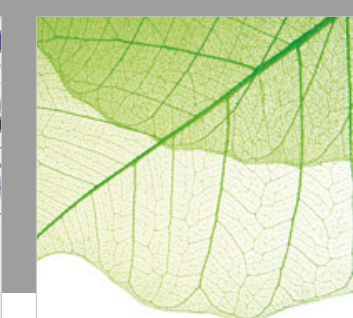

Journal of Botany

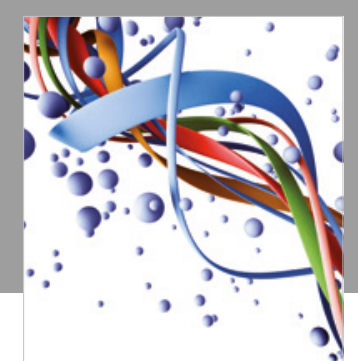

Scientifica

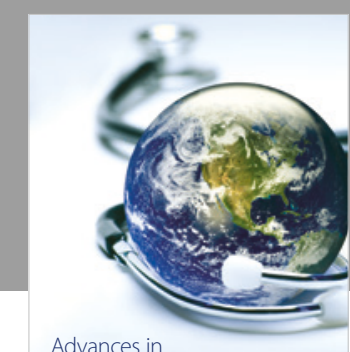

Public Health

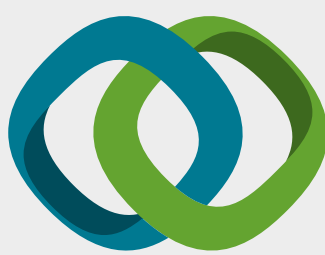

Hindawi

Submit your manuscripts at

www.hindawi.com
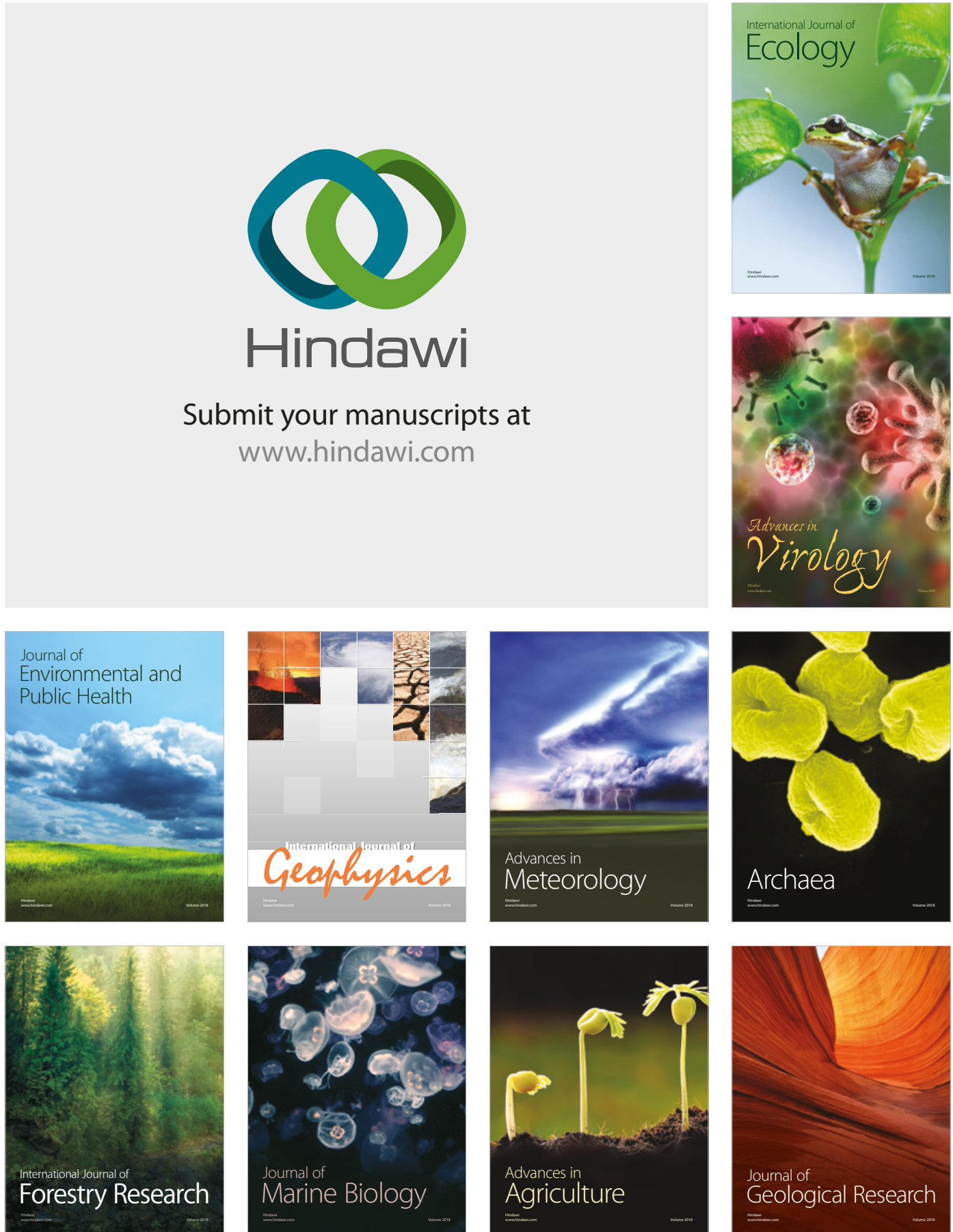

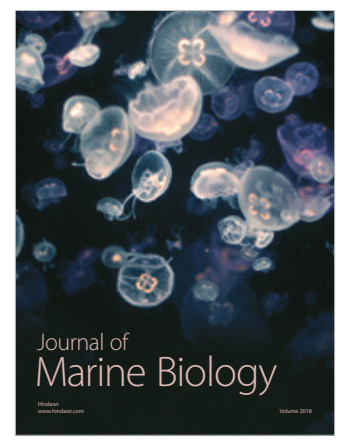

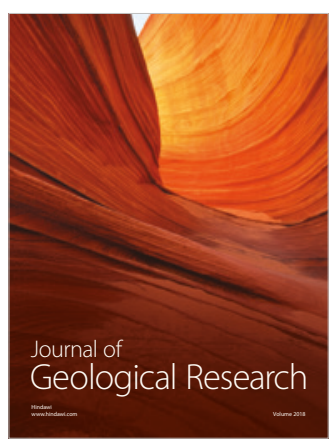

